\title{
Waves of mission amongst South African Baptists
}

\begin{tabular}{|c|c|}
\hline \multicolumn{2}{|c|}{$\begin{array}{l}\text { Authors: } \\
\text { Desmond Henry }{ }^{1,2} \\
\text { Cornelius J.P. Niemandt² }\end{array}$} \\
\hline \multicolumn{2}{|c|}{$\begin{array}{l}\text { Affiliations: } \\
{ }^{1} \text { Department of Missiology, } \\
\text { Baptist Theological College, } \\
\text { South Africa }\end{array}$} \\
\hline \multicolumn{2}{|c|}{$\begin{array}{l}{ }^{2} \text { Department of Science of } \\
\text { Religion and Missiology, } \\
\text { University of Pretoria, } \\
\text { South Africa }\end{array}$} \\
\hline \multicolumn{2}{|c|}{$\begin{array}{l}\text { Correspondence to: } \\
\text { Cornelius Niemandt }\end{array}$} \\
\hline \multicolumn{2}{|c|}{$\begin{array}{l}\text { Email: } \\
\text { nelus.niemandt@up.ac.za }\end{array}$} \\
\hline \multicolumn{2}{|c|}{$\begin{array}{l}\text { Postal address: } \\
\text { PO Box 50710, Randburg } \\
2125 \text {, South Africa }\end{array}$} \\
\hline \multicolumn{2}{|c|}{$\begin{array}{l}\text { Dates: } \\
\text { Received: } 15 \text { Feb. } 2013 \\
\text { Accepted: } 28 \text { Oct. } 2013 \\
\text { Published: } 30 \text { Apr. } 2014\end{array}$} \\
\hline \multicolumn{2}{|c|}{$\begin{array}{l}\text { How to cite this article: } \\
\text { Henry, D. \& Niemandt, C.J.P., } \\
\text { 2014, 'Waves of mission } \\
\text { amongst South African } \\
\text { Baptists', Verbum et Ecclesia } \\
\text { 35(1), Art. \#843, } 8 \text { pages. } \\
\text { http://dx.doi.org/10.4102/ } \\
\text { ve.v35i1.843 }\end{array}$} \\
\hline \multicolumn{2}{|c|}{$\begin{array}{l}\text { Note: } \\
\text { Dr Desmond Henry is a } \\
\text { Research Associate of the } \\
\text { University of Pretoria. }\end{array}$} \\
\hline \multicolumn{2}{|c|}{$\begin{array}{l}\text { Copyright: } \\
\text { (C) 2014. The Authors } \\
\text { Licensee: AOSIS } \\
\text { OpenJournals. This w } \\
\text { is licensed under the } \\
\text { Creative Commons } \\
\text { Attribution License. }\end{array}$} \\
\hline \multicolumn{2}{|l|}{ Read online: } \\
\hline 口ifipar & $\begin{array}{l}\text { Scan this QR } \\
\text { code with your } \\
\text { smart phone or } \\
\text { mobile device } \\
\text { to read online. }\end{array}$ \\
\hline
\end{tabular}

Baptists in South Africa have developed along lines similar to other denominations of their day (e.g. the Dutch Reformed Church). However, there are six distinct waves of development within Baptist history in South Africa (including an emerging wave) that showcase the growth, development, digressions, limitations and transformation that has taken place in the Baptist denomination in South Africa. These waves are a tremendous help to the Baptist Union of Southern Africa (BUSA) as they seek to be faithful witnesses in the 21st century and beyond. It has become clear: If BUSA is to succeed within the emerging wave of mission and development, it will need a new, updated map to guide them where many have not been before - or BUSA could simply fade into irrelevance in South Africa, impacting other movements and denominations in turn.

\section{Introduction}

Understanding a denomination's history is an important undertaking by its members and theologians. It is important for various reasons, one of them being a continued, healthy future unaffected by historical trends and issues. Interestingly, Baptists in South Africa have developed along similar lines to other denominations of their day (e.g. the Dutch Reformed Church) but have always remained secondary in growth and numerical significance when compared to their counterparts. The author has developed a way of looking at South African Baptist history in terms of six distinct waves of development (including an emerging wave) that showcase the growth, development, digressions, limitations and transformation that has taken place in the Baptist denomination. These waves are a tremendous help to the Baptist Union of Southern Africa (BUSA) as they seek to be faithful witnesses in the 21st century and beyond. It has become clear: If BUSA is to succeed within the emerging wave of mission and development, they will need a new, updated map to guide them where no many have been before - or BUSA could simply fade into irrelevancy in South Africa, impacting other movements and denominations in turn.

\section{Waves of Baptist mission and development}

Seeking to understand Baptist history within South Africa is best achieved within paradigms relating to historical and spiritual frameworks within which one can easily interpret such events. Bosch, in his summa missiologica 'Transforming Mission', illustrates the importance and proportionate effect of understanding paradigms in mission and of mission.

Saayman's (2007) historical overview of the Dutch Reformed Church's (DRC) mission, Being missionary, being human, presents the reader with four waves of mission that in many respects categorise the mission of the DRC within South Africa. Saayman's overall work on the mission of the DRC has some parallels with the mission of BUSA although the latter's history is more recent within the South African context and commences, historically speaking, in the second wave of DRC history in South Africa. We do not attempt to analyse the accuracy of Saayman's interpretation of the DRC's waves of mission and recognises that, perhaps, the inadequacy of Saayman's fourth wave was addressed by Niemandt (2012). Rather, we adopt the concept of paradigms as semantically illustrated through 'waves of mission', which find application and relevancy in the BUSA and her history within South Africa or southern Africa.

What follows, then, in the waves below is a brief overview of the important trends that have shaped, in some or other way, the history of Baptists within South Africa. This is an important history. In the words of Warren (1967:11), if a Christian 'takes seriously the doctrine of the Incarnation and its implications for the understanding of history, he [or she] must take all history seriously'. This history cannot in any way be separated from secular history as both mission and secular history, in many respects, form two streams which unite and commingle (cf. Du Plessis 1911:viiviii). It is impossible to study this history without taking into consideration religion, politics and culture alongside the British, German and 'local' blend of South-African Baptists. Saayman's 
(2007:20-34) 'waves of DRC mission' are as follows: the first wave (1779-1834) is termed a 'reflection on the early Dutch Reformed Mission'. The second wave (1867-1939) describes the DRC's mission work in terms of crossing borders with a distinct mission focus on areas outside the borders of the Cape Colony of the time. The third wave (1954-1976) is described as a crossing of 'inner boundaries'. This era must be understood against the political background and unrest of the time in apartheid South Africa. The fourth wave began around 1990 with F.W. de Klerk's unbanning of all black liberation movements. During this time, Saayman argues, the Afrikaner's self-understanding began to change, which brought some doubts about the Afrikaner's place in South Africa. This wave of mission has several interpretations depending on one's perspective, however. As the DRC started to grapple with a missional ecclesiology in this era, it did not only see mission as distinctly to the 'ends of the world' but reflected on their self-preservation and withdrawal.

In our analysis of the DRC's distinct waves of mission in South Africa, extensive correlation was identified between the BUSA and the DRC, but it also included several points of difference. However, Saayman's paradigms of mission history serve as an important and helpful impetus for the interpretation of the Baptist work in South Africa. SouthAfrican Baptist history commences within the second wave of mission described in the DRC's waves of mission and has some connecting points with a number of the other waves described by Saayman. The South-African Baptist 'waves of mission' would look something like Figure 1.

\section{Wave one: $1820-1877$}

\section{Years of settlement and formation}

This era saw the arrival of both British and German settlers to the Eastern Cape and the settlement and development of Baptist churches in the newfound colony. Baptist work, however, progressed slowly in comparison with other denominations of the day (e.g. Methodists, Anglicans). This slow growth was due, in part, to the lower numbers of Baptist immigrants, the agreement reached between them and the London Missionary Society, their view of Baptism, a lack of trained pastors and church strife in the form of theological differences amounting to Calvinistic or Armenian

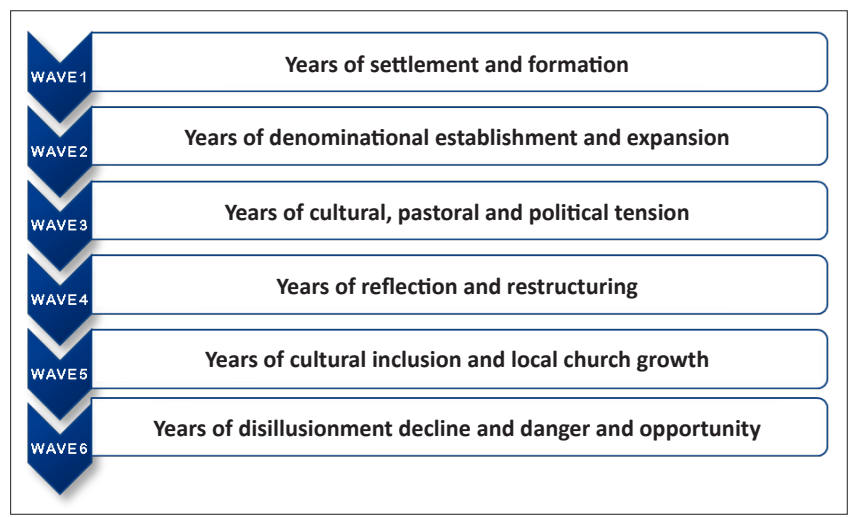

FIGURE 1: Baptist Union of Southern Africa waves of mission. polarisations. The first Baptist church met in Lower Albany under a tree on a farm owned by Mr Stephen Smith (senior deacon of the Grahamstown church) (Batts n.d.:4). In this era, the pastoral leadership of churches was undertaken by lay leaders and preachers who made themselves available to Baptist work amongst the European settlers - Outreach was primarily to settlers (due to the said agreement above). After the settlers were relocated, they met in a small cottage erected by Mr William Shepherd after which the carpenter's shop was used. Informal meeting venues and sharing of property seemed to be a predominant feature of the early days of settlement and Baptist growth.

Shortly after the inception of the Grahamstown church, a dispute arose over Mr Miller's teaching and doctrine. Similar issues seem to have continually been a discussion point amongst Baptists and have led to many debates and schisms since the days of settlement. In 1843, the first church building was opened in Bathurst Street in Grahamstown, followed in 1851 by the opening of the Hill Street Baptist Church in Grahamstown where Mr William Hay served as pastor. Mr Hay found it difficult to work with the entrenched hyperCalvinistic element in the Bathurst Street Church and planted this new work nearby. These churches later amalgamated and met at the Bathurst chapel (cf. Christofides 2009:160).

\section{Wave two: 1877-1950s}

\section{Years of denominational establishment and expansion}

This era saw the rather incidental, possibly premature, beginnings of BUSA, the era of denominational growth and the establishment of a missions strategy to reach both settlers and indigenous 'natives' (with the help of Gutsche and the German Baptists, especially).

Years of growth in missionary involvement of local churches: In this era, there was focussed attention on extension work. A number of other Baptist churches were founded in main centres like Port Alfred, Graaff Reinet, Pretoria, Cape Town, King Williams Town, Port Elizabeth and towns in the then Transvaal. However, given their innate focus on settlers, there was a growing dependence on trained pastors from England and Germany respectively. This, as is seen in later times, reflected a lack of leadership succession and training which in turn fostered greater schism amongst Baptists in South Africa (Batts n.d.:47).

Important to this era was the formation of the South African Baptist Missionary Society (SABMS) in 1892 as a separate entity (following the British model) to BUSA with the aim of reaching the heathen indigenous people inhabiting South Africa (Reid 1976; cf. Roy \& Hudson-Reed 2001). Hugo Gutsche (German) was instrumental in its formation. Missionary zeal characterised German Baptists, and their mission endeavours were surprising and led to the bulk of the growth experienced in BUSA in this era. Reid (1976:10) comments that 'the missionary society is the Union in action'. In 1898 , it was recorded that the growing missionary interest of the Cape Town Baptist Church led to the formation of 
the Cape Town Auxiliary which supported a missionary couple entirely (Reid 1976). Similarly, it would seem that the Troyeville Church and the Natal Missionary Society became affiliated as auxiliaries, bringing the mission of the Baptist Church closer to home. Unfortunately, due to strict rules being imposed by the SABMS, missionary auxiliaries were 'a relatively short-lived phenomenon' (Reid 1976:17).

Additionally, the formation of the Bantu Baptist Church (BBC) in 1927, for the purpose of 'enabling the Bantu churches to carry on the work started by the white missionaries, supported by the Society, under their own auspices' (Reid 1976:22) was a pivotal point in the history of South African Baptist mission endeavours. From the side of the BUSA, this effort was made to mark the church as belonging to the Bantu people, creating a special environment where their abilities and various gifts could be exercised and where closer cooperation could be practiced (cf. Reid 1976:22, 23). However, this initiated an era of contention between the newly-formed BBC, SABMS and BUSA as they continued to exercise parental control (colonial tendency). Reid (1976), referring to the 1827-1828 South African Baptist Handbook (South African Baptist Handbook [SABH] 1827-1828:19), states in Hudson-Reed and Holmes (1995):

... there was still to remain the 'parental control' of the South African Baptist Missionary Society and any resolutions of the churches, councils or assembly were subject to the vote of the Committee of the South African Baptist Missionary Society. (p. 57)

This situation was referred to by Reid (1976:25) as the 'socalled "euthanasia of mission"', and sadly, we see the Baptist work in South Africa developing along the lines of separate development akin to the political thinking of the day.

Unfortunately in this era, there was great divergence from the role of the local Church in missions. In fact, this problem was evident from the 4 th century AD where missionaries were a 'special category' of church worker, sent to the frontiers of civilisation to propagate the faith amongst unbelievers and incorporate them into the church. Furthermore, we argue that this view is still prevalent in 21st century Africa. Historically speaking, during this era, mission was no longer something done by every local congregation. It developed into a separate activity carried on by special agents in remote areas. This understanding dominated our thinking until recent times. The church had, in many respects, lost its missionary nature. Few lasting efforts were made to rectify this.

\section{Wave three: 1960s-late 1980s}

\section{Years of cultural, pastoral and political tension}

Given the unjust policy of apartheid, which was implemented and enforced by the South African Nationalist Government from 1948 to the early 1990s, this era marked an increase in apartheid promulgation which infected and affected church life and praxis amongst Baptists. During this period, many evangelical churches, including Baptists, were influenced by the socio-political status quo. This, however, does not exclude the fact that many individuals did not adhere to the status quo. However, it did reflect something of the prevailing attitude of the time.

Indicative of the trend described above, most of the leadership positions and national standing committees were mainly occupied by and consisted of members from the white community (SABH 1960-1961). BUSA and the Baptist Theological College (BTC) apparently held on to the status quo dictated by the Nationalist government. This is shown in their treatment of 'other-than-white' students at their Park Town campus in Johannesburg, for example, not allowing them to reside in the hostels. Scheepers (2008:32) states that the BTC leadership adhered to the governmental ruling stating that only two Bantu students were allowed to study at BTC over a 4-year period. Scheepers (2008), however, recognised that John Hiebner, a school teacher from the coloured community in Cape Town, was the first and only 'other-than-white' to study at BTC in Johannesburg, from 1953-1955. Eric Hermanson in an interview (September 2012) stated that BTC did not have any applications from Bantu students, which would perhaps be indicative of their adherence to any such policy or ruling as promulgated by Scheepers relating to the acceptance of black and coloured students at the time.

Proof of BUSA's complacency with regard to the status quo is provided by Scheepers (2008) in reaction to the government's relocation of 'other-than-white' people. However, Baptists responded in 1966 by taking up a national Christmas appeal, which was then earmarked for coloured churches forced to relocate because the impending Group Areas Act would have come into effect shortly thereafter. Scheepers (2008) points out that many Anglicans, Roman Catholics and Muslims refused to comply with this inhumane act. However, Baptists unfortunately complied and went along with the status quo (Baptist Union Executive Minutes 1966:170).

There were also some positive developments in this era. Due, in part to Dr Chris Parnell, in October 1964, the Rev. A.J. Maye represented the newly formed South African Association of Coloured Churches as the first 'other-thanwhite' representative on the BUSA executive since 1877. This was followed in 1966 by the first Indian representative and in 1966 by the formation of the Baptist Convention. However, during this time, members of the BUSA executive were representatives of ethnic groups rather than member churches.

\section{Wave four: 1970s-1980s}

\section{Years of reflection and restructuring}

During this decade, much time was spent in evaluating the past, analysing the present and preparing for the future of BUSA with specific regard to its structures. Scheepers (2008) comments on this development in BUSA as part of his master's dissertation, 'A critical analysis of the structural dynamics operative within the Baptist Union of Southern Africa (BUSA) from 1960-2005 and an evaluation of these dynamics in the light of BUSA ecclesiology'. 
Years of reflection: There were two important developments that occurred in this era: the withdrawal of the South African Baptist Alliance (SABA) from BUSA and the establishment of the Cape Town Baptist Seminary (CTBS).

In 1977, the SABA (formerly the South African Association of Coloured Churches) withdrew from the BUSA executive and was dissolved. In my correspondence with Hermanson (February 2012), he stated that it was the coloured churches themselves who decided that they wanted to be recognised as Baptists and not as coloured Baptists. As most of them were in the then Western Province, they felt that they should all be part of the Western Province Baptist Association (the second largest BUSA Association) and BUSA and that there was no need at all for another organisation for them, especially as their actions could be construed as promoting an apartheid structure.

The 1972 BUSA Assembly agreed to the establishment of the Western Province branch of the Baptist Theological College of which Dr Chris Parnell was the first principal. Although it was primarily founded as a coloured training centre, it quickly grew to be multi-cultural and is known today as the Cape Town Baptist Seminary, well-known for its fair racial representation amongst students and faculty and located within a township in Cape Town.

Years of structural change: The 1980s can be viewed as the years of structural change within BUSA. Many structural developments, which had tremendous implications for the ministry within BUSA, were initiated.

Scheepers (2008) summarises these developments as:

- changes to the National Executive

- changes to the overall structure of BUSA

- changes to the missions philosophy of BUSA, from the SABMS to the BMD

- changes in the relationship between BUSA and the BCSA

- changes regarding theological education. (p. 51)

Additionally, the Rev. Ron Hendricks from the coloured community became the first 'other-than-white' vice-president of BUSA. He was inducted at the 1988 King Williams Town Assembly. George Ngamlana followed suit as the next 'otherthan-white' representative elected as Associate General Secretary of BUSA from 1994 to 1997. In 1999, Ngamlana became the Area Coordinator of KwaZulu-Natal and the first black BUSA missionary to Africa (Zambia) in 2005. Sydney Dyasi became the Area Coordinator of the Border Baptist Association in 2000 - indicative of a growing corrective trend within BUSA.

The BUSA executive, in an attempt to bridge the prevailing cultural gap within the Union, gave full voting rights to the Afrikaanse Baptiste Kerk (ABK) [Afrikaans Baptist Church], the Baptist Convention of Southern Africa (BCSA), the Indian Baptist Mission (IBM) and the Natal Indian Baptist Association. This was done in spite of the fact that the bulk of their churches were not members of BUSA. Thus, dual membership was given to special associations of BUSA.
The coloured community was unfortunately excluded from participation on the National Executive of BUSA due to the disbandment of the South African Baptist Alliance in 1977. Their inclusion into a predominantly white BUSA took longer than expected and gave rise to numerous expressions of unhappiness. The walkout at the 1989 Kimberly Assembly (held at the South African National Defence force military barracks) is an example of the prevailing unhappiness with the policy and praxis of BUSA.

The policy of devolution (previously referred to as the workreview proposal) was accepted at the annual Assembly in 1978 and implemented in the 1980s. This policy can be viewed as an attempt by the BUSA executive committee to 'take the Baptist Union to the Territorial regions and local churches and make them feel an integral part of it' (Scheepers 2008:38). Although initially seen in a negative light, the policy of devolution resulted in the better functioning and greater involvement of Associational Executives, the appointment of Area Coordinators and the development of Associational Ministry committees.

Changes to the missions philosophy of BUSA were welcomed and led to the formation of the Baptist Missions Department (BMD). This, amongst other things, contributed to the renewed focus on the local church as a primary agent of mission. Additionally, the role of the BMD was to equip local churches and to assist them with regard to the training, selection and sending of missionaries. This era saw the transformation of BUSA's missiology and signalled the end of paternalistic and colonial-style missions. Missions was no longer white to black: ‘[e]verybody, regardless of culture or colour, could now be missionaries ...' (Scheepers 2008:67). Hermanson, in an interview in February 2012, stated that the limitations on missionary manpower then related to a limitation of space as they mostly had missionary superintendents, which left little room for people to serve in other capacities. As a result, young people who felt called to missions joined non-denominational mission organisations. Indicative of this trend, the BMD recognised all these people as Baptist missionaries - there is a list of 20 pages of names in the 2010-2011 South African Baptist Union Handbook (SABH 2010-2011). Hermanson also remarks that, even within this era, there were exceptions, which were an expression of the good will of BUSA. One such example is Julia Forgus (coloured), who was a SABMS missionary amongst the Indians in the then Natal from 1959 until she went overseas for study leave in 1981 (after which the SABMS ceased to exist). Hermanson (in correspondence dated February 2012) insists that race was not taken into account at all when it came to missionary service.

The 1980s saw the breakdown of the relationship between the BCSA and BUSA. These were years of great excitement and contention as far as a merger between the two bodies was concerned. However, in 1987, the BCSA withdrew its Associational status from BUSA, and in 1988, the Baptist World Alliance annual meeting granted membership status to the BCSA, which saw the final parting of the ways between BUSA and the BCSA (Scheepers 2008:73). 


\section{Wave five: 1990s-2000s}

\section{Years of cultural inclusion and local church growth}

The 1990 BUSA presidential address surprised many delegates and served as a watershed for transformation within BUSA. Terry Rae, BUSA General Secretary at the time, urged BUSA to move towards further racial participation and recognition within all levels of BUSA.

A new dynamic and dimension with regards to attitude, approach, progressive thinking and bold leadership characterised the BUSA executive.

The BUSA executive was instrumental during this decade in leading BUSA through major structural changes, namely the composition of the BUSA executive and the phasing out of Special Associations.

The Baptist Women's Department and Baptist Youth of South Africa became official boards of BUSA and were represented at the National Executive. Additionally, BUSA Care was established to address social concern and empower deprived communities.

In 1991, the Ministry Board was established. The board's main function related to application for ministerial recognition and adherence to ministerial regulations.

In 1991, there was a definite change in attitudes toward race and gender issues, and BUSA took a proactive stance towards being non-racial in both practice and leadership (Baptist Union Executive Minutes 1991:29). Furthermore, in 1991, BUSA reasserted its unequivocal rejection of apartheid as a sin, and it committed itself to work towards the establishment of a just society in South Africa (BUSA Executive Minutes 1991:30).

The growing improvement in race relations is indicated by the proposal made by Peter Holness, received at the 1996 Assembly held in Port Elizabeth. The concept 'Impact 2001' was accepted in principle by the assembly as it seeked to work toward fuller cultural and gender inclusivity (SABH 1996-1997).

The relationship with the BCSA was taxing since its withdrawal from merger talks in 1987. However, through a series of events, a breakthrough came in 1997 when the BUSA executive agreed to make a formal statement to the Truth and Reconciliation Commission containing, amongst other points, a confession of the sin of omission in that BUSA did not do enough to oppose the structures and status quo (Baptist Union Executive Minutes 1997:30). The Colesberg resolution in May 1998 was an historic turning point, and subsequent meetings affirmed that both BUSA and BCSA stood on the same doctrinal ground and that reconciliation is imperative but will take time to permeate to the grassroots (churches) and to Territorial Associations.

Church-growth initiatives were a main focus of the 1990s within BUSA. Some of the largest numbers in terms of growth were recorded during this period although some of this can be attributed to the amalgamation of the former Transkei Baptist Union and former BCSA churches that joined BUSA.

\section{Years of new developments}

The new millennium was inaugurated with a conference entitled 'Baptists in the $21^{\text {st }}$ Century' and was held at the Gariep Dam in February 2000. The focus of the conference was on the following:

- a new emphasis on youth and children (change of perception towards youth and children's ministry was needed)

- social action linked to mission and evangelism (main components of this vision included ministry to HIV and AIDS sufferers, job creation and disaster relief)

- a renewed national and associational thrust on mission and evangelism (the focus here remained on Associational church planting, reaching Muslims in South Africa, innercity ministry and every church being a mission church)

- developing and promoting multi-cultural partnerships and gender equality whereby stronger churches would help weaker ones within BUSA

- the continuation of affordable theological education to all cultural groupings within South Africa with a greater sense of intentionality regarding the appointment of black lecturers at BTC and CTBS

- Baptist Union structures, particularly as they relate to Associational boundaries, and the role of BUSA'S general secretary to be revisited

- the pastoral care of the Ministry Board relating specifically to those under discipline was to come under review (SABH 2000-2001:366-367).

Another significant happening in this decade was the establishment of the South African Baptist Alliance in August 2001 where five autonomous Baptist bodies formed this alliance in order to build good relationships, cooperate in evangelism and church-planting efforts and become a united voice against ethical, moral and spiritual decline in South Africa (SABH 2001-2002:247).

In November 2002, a 'Bosberaad' [a meeting of the minds] was held in order to discuss key issues relating to the structure of BUSA, the ethos of BUSA, local church 'buy-in' to BUSA, functions of Area Coordinators and the two theological colleges. Recommendations were made to the BUSA executive with respect to the restructuring of central functions, annual Assembly, the BUSA executive and colleges. 'Equip 2005', with a focus on training and discipleship, is the main emphasis in this new millennium of Baptist work and witness in South Africa. Furthermore, in May and June 2004, the National Impact Consultation was held at Hilton Baptist Church. 'Impact' can be described as one of the few inter-generational BUSA conferences held to date. At 'Impact', statistical data relating to over 12 years of BUSA ministry were reviewed, and trends were discussed in great detail. Then, 2004 was a year of great uncertainty within BUSA as six of the seven Associations were without Area Coordinators. The 2004 
Assembly appointed a 12-person commission to investigate the leadership structures and financing of the Union and submit a report to the 2005 Assembly (SABH 2004-2005). The uncertainty continues into the second decade of the next millennium. A positive step was nonetheless taken when the 2004 Assembly mandated the BUSA executive to appoint a person to spearhead the development of a Department of Pastoral Care. Unfortunately, due to financial constraints, this appointment was only implemented in June 2007 with the 'part-time' appointment of a retired pastor, Rick Inglis.

BUSA's 'Equip 2005' vision was followed by 'Impact 2010', adopted at the 2005 Assembly. This, in the light of Impact Consultation and the Lekkeroord Declaration (cf. SABH 20032004) will have the following outcomes:

- renewed focus on spiritual renewal - prayer

- doubling the BUSA membership

- doubling the number of churches

- doubling the number of children and youth being ministered to in our churches

- doubling the number of children workers or Sunday School teachers

- at least 300 'missions involved' sending and caring churches

- at least 300 churches with active youth and young adult ministries

- development of regional consultancies

- an effective pastoral-care mentoring programme in place.

Additionally, the 2010 World Cup hosted by South Africa and the role and possibility of mission impact on our local communities during this time was a great impetus and driving factor within the orbits of 'Impact 2010'. We are not sure if we achieved all the goals above, but there was some 'energy' on the ground! A new post-2010 focus was launched with the intention to sharpen the focus on the local churches in the areas of membership, leadership, ministry, missions and communities (SABH 2009-2010). This post-2010 focus is known as 'Local church alive' and intends to move BUSA churches toward diversity, ministry, disciple-making, being process-driven, selflessness and inclusivity (SABH 20092010).

\section{Wave six: Years of disillusionment, decline, danger and opportunity (2010-present)}

\section{Context of findings for the emerging wave}

The previous wave has in many respects set the scene for what is currently unfolding in the BUSA. We feel that there may have been signs in the fifth wave that have raised deep concerns that BUSA has not been progressive enough in its praxis. The first concern was seen in the disregard of critical thinking on the part of the BUSA leadership regarding the future ministry of the Union of Autonomous Churches. This is seen in Scheeper's master's dissertation, focusing significant time on historical developments and polarisation without dealing effectually and critically with some of the changes evident within the current era. Additionally, Peter Christofides (2009) conducted research relating to the lay involvement of members of BUSA churches and presented findings that were pertinent, yet remained unpublished in our own theological journal and was not dealt with at national or regional Baptist meetings. This shows, in some way, a disregard for the voices of the theologians and missiologists within BUSA, which, if it continues, will lead to further decline and discontinuity within BUSA in future. This, to some extent, led us to using BUSA as the primary interlocutor in the doctoral work (written by Henry) that forms the foundation of this article. In the doctoral dissertation entitled 'Leading toward missional change: An Afro-centric missional perspective on the history of South African Baptists', I (Henry 2013) unpack the results of a mixed-methods research approach toward the present state (and future) of BUSA in the light of historical trends evident since 1994. The research described above has been broken up into segments (survey, data analysis and interviews), which give both broad strokes and finer details that may be of help in interpreting trends in BUSA and that may assist in aligning BUSA's focus within the next wave of Baptist history in the making. It is important for us to mention this research within the sixth wave of BUSA so that the reader will be familiar with the methodology employed and some of the conclusions reached herein (cf. Henry 2013).

Research into this wave was conducted in the Baptist Union Archives, located at the Baptist Theological College in Randburg. This primary research reveals some of the denominational trends since the inception of our Rainbow Nation in 1994. Following this stage, the results of the 'Missional Church Survey', which have been collated to give 'impressions' or 'snapshots' of local churches and where they see themselves presently, were analysed extensively in conjunction with the data collected from BUSA's archives. This has been helpful in identifying micro-trends at the grass-roots level and represents the bulk of my quantitative research approach. Lastly, an important part of my mixedmethods methodology includes qualitative research, which has come from the following sources:

- structured interviews with BUSA staff

- informal interviews with leaders involved with BUSA mission (past and present)

- informal interviews with our BUSA seminary staff and principals

- informal interviews with local-church pastors representing a reasonable segment of most of our provinces and racial divides

- informal interviews with church members and leaders representing a reasonable segmentation of most of our provinces and racial and economic divides.

This qualitative research, in my approach, is what ties all other components together and holds the mosaic of what represents a growing challenge for the continuation and further growth of BUSA witness in South Africa and the rest of Africa. The importance of understanding ministry and mission in this wave, as history in the making, is invaluable for the formation of relevant and contextual means of correction. 


\section{A brief summary of research findings}

The limitations of my research are quite clear with regards to both the availability and accuracy of statistical data sourced from the SABH. The annual return rate on statistical data from a local-church level is sporadic and inconsistent, and no clear overall picture can be drawn from this data in effectively tracing trends within our union of churches due to a continuous low rate of response from local churches. This in itself needs to be addressed by the BUSA Executive Committee who seems to be unconcerned about the accuracy and type of questions that are asked. If any informed leadership decisions are to be made and implemented, it needs to be from a basis of reliable information, which is sorely lacking in BUSA. We employed a mixed-methods approach to this study with a weighting in the qualitative research aspects, which have shown more accurately what the emerging trends are and have filled the evident research gaps in the quantitative fields.

What can one deduce from the data collected and analysed from BUSA records? The percentages shown in Table 1 are indicative of the contemporary BUSA scene from a statistical perspective, which is characterised by pastoral indifference, church inefficiency, member apathy and overall denominational decline. This conclusion has not been reached independently and subjectively. Rather, it is based on personal observations and personal conversations with BUSA's leaders at almost every level: national, regional and local and in most positions (pastors, Area Coordinators, staff at Baptist House, theologians, etc.). It is also confirmed by data collected from both qualitative and quantitative research conducted nationwide.

Table 1 reveals that there has been no growth in the number of churches added to BUSA since 2006. Many would argue that these figures are inaccurate and do not fairly represent the current situation. Such was the case at the June BUSA executive meeting where a comment by the outgoing president, Reuben Ihlenfeldt, was illustrative of the attitude described above. However, they cannot back up their comments with any real substantive data or proof of an alternative pattern. This situation does not represent stability. Rather, as other data will reveal, it represents a downward spiral all round. BUSA membership has decreased by $4 \%$ during the period 2006-2011. A further decline in growth of $34 \%$ has been experienced in adherents to BUSA churches. All in all, this represents a negative growth rate of $12 \%$ when combining membership and adherents of BUSA. This is nowhere more evident than in the decline of the Youth ministry within BUSA at national, regional and local level, and we should be less concerned with the actual variances in percentage within the current statistics and recognise that we live in an era or decline within BUSA.

Within our constituency, there has been a $54 \%$ decrease in teachers overall, which is perhaps why we have experienced a $60 \%$ decrease in children, a $64 \%$ decrease in youth and a $54 \%$ decline in young adults who associate with or affiliate to a local BUSA church. Given the fact that South Africa's population is predominantly young, the presents an epic challenge to sustainable ministry within BUSA churches nationwide.

Other indicators further describe the major decline experienced in BUSA in recent years: baptisms (-49\%), churches or fellowships planted $(-19 \%)$, churches assisted $(-56 \%)$ and missionaries supported $(-35 \%)$. The figures are indicative of the crisis in which BUSA finds itself, and if left unattended, BUSA will fade into irrelevance within this next decade or so.

Given the data above concerning the decrease in BUSA membership and the lack of leadership involvement in children, youth and young adult ministry, is it reasonable to deduce that those who are leaving BUSA churches are many of the leaders, who in previous years have been pillars of stability and support, who no longer have confidence in the general direction of BUSA churches and structures within the new South Africa? Given the data above, this is perhaps more than reasonable; it is highly probable! It seems to me that it should be the urgent undertaking of BUSA's

TABLE 1: Baptist Union of Southern Africa statistical summary 2006-2011.

\begin{tabular}{|c|c|c|c|c|c|c|c|}
\hline Churches & 2006 & 2007 & 2008 & 2010 & 2011 & $\begin{array}{l}\text { Percentage change } \\
\text { from } 2006 \text { to } 2011(\%)\end{array}$ & 5-year average \\
\hline Number of churches & 501 & 505 & 515 & 524 & 500 & 0 & - \\
\hline Statistics submitted & 261 & 194 & 202 & 196 & 145 & - & 200 \\
\hline Members & 45329 & 44626 & 45270 & 43431 & 43545 & -4 & - \\
\hline Adherents & 17559 & 21409 & 23174 & 22213 & 11555 & -34 & - \\
\hline Members and adherents & 62888 & 66035 & 68444 & 65644 & 55100 & -12 & - \\
\hline Teachers & 2863 & 2825 & 2868 & 2883 & 1319 & -54 & - \\
\hline Children & 24720 & 25520 & 27983 & 27320 & 9967 & -60 & - \\
\hline Percentage children of membership (\%) & 55 & 57 & 62 & 63 & 23 & - & - \\
\hline Youth & 9732 & 10441 & 12842 & 9999 & 3524 & -64 & - \\
\hline Percentage youth of membership (\%) & 21 & 23 & 28 & 23 & 8 & - & - \\
\hline Young adults & 3861 & 4077 & 4247 & 3661 & 1785 & -54 & - \\
\hline Percentage young adults of membership (\%) & 9 & 9 & 9 & 8 & 4 & - & - \\
\hline People trained & - & - & - & - & 421 & - & - \\
\hline Baptisms & 1732 & 1382 & 1406 & 1337 & 884 & -49 & - \\
\hline Churches or fellowships planted & 42 & 43 & 54 & 56 & 34 & -19 & - \\
\hline Churches assisted & 293 & 364 & 371 & 438 & 128 & -56 & - \\
\hline Missionaries supported & 876 & 873 & 1032 & 936 & 568 & -35 & - \\
\hline
\end{tabular}


current executive to address the issues outlined in this article (and within the dissertation mentioned above). However, the problem lies with the fact that decisions are made by leaders who are not really representative of the segments of people BUSA has lost recently, and the executive have little knowledge of how to rectify this situation independently of BUSA's youth and young adults and their respective leaders.

What is evident is that BUSA is in an era of incredible opportunity or danger. It needs the recognition that any serious consideration of the magnitude of the task needs to be meted with the realisation that a new map is needed to guide BUSA towards fuller engagement within its constituency locally and regionally. The recent proposal to the BUSA executive from the Baptist Northern Association (proposed from the floor of their annual general meeting [AGM]) highlights the fact that, in the view of our strongest Association, BUSA will only progress into the future if it takes serious its mission at local level, allowing the Associations to co-ordinate ministry and the BUSA to do what it is mandated to do administratively and regionally through the development and strengthening of Associations.

\section{Conclusion}

The situation we face in BUSA today is unlike any other we have faced before, and we are unable to quantify the current prospects. Suffice it to say that, if these trends continue, BUSA's future will be undeterminable and its influence will be ever-diminishing and irrelevant to the real needs of society, pastors, churches and the mission at large. This decade is therefore of great significance to BUSA and is the era of reaction and rediscovery - reaction against the status quo in BUSA leadership and a rediscovery of the missional nature of God and his church. It is important for BUSA to recognise the importance of this era and rise to the task of missional engagement for its continued providence.

\section{Acknowledgements Competing interests}

The authors declare that they have no financial or personal relationship(s) that may have inappropriately influenced them in writing this article.

\section{Authors' contributions}

C.J.P.N.(University of Pretoria) was responsible for conceptual contributions and missiological insight and supervision of the research project, D.H. (Baptist Theological College) was the researcher responsible for the implementation of the original research proposal and outworking of the project from first principles to outcomes.

\section{References}

Batts, H.J., n.d., The story of 100 years, 1820-1920 being the history of the Baptist church in South Africa, T. Maskew Miller, Cape Town.

Baptist Union Executive Minutes, June 1966.

Baptist Union Executive Minutes, March 1991.

Baptist Union Executive Minutes, June 1997.

Christofides, P., 2009, 'The rediscovery of the role of the laity in the mission of the church - with reference to the Baptist Union of Southern Africa (BUSA)', PhD Thesis, Dept. of Science of Religion and Missiology, University of Pretoria.

Du Plessis, J., 1911, A history of Christian mission in South Africa, Longmans Green, London.

Henry, D., 2013, 'Leading toward missional change: An Afro-centric missional perspective on the history of South African Baptists', PHD Thesis, Dept. of Science perspective on the history of South African Baptists',
of Religion and Missiology, University of Pretoria.

Hudson-Reed, S. \& Holmes, R., 1995, 21 years of service, Baptist Historical Society, Cape Town.

Niemandt , C., 2012, 'Kontoere in die ontwikkeling van ' $n$ missionêre ekklesiologie in die Nederduitse Gereformeerde Kerk: 'n Omvangryker vierde golf', Nederduitse Gereformeerde Teologiese Tydskrif 51(3), viewed 27 August 2013, from http://

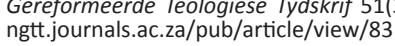

Reid, D.A., 1976, 'An evaluation of the policies of the South African Baptist Missionary Society prior to 1971', Dip.Th Thesis, Baptist Theological College.

Roy, K. \& Hudson-Reed, S., 2001, No turning back, South African Baptist Historical Society, Pinelands.

Saayman, W., 2007, Being missionary being human, Cluster Publications, Pietermartizburg.

Scheepers, A., 2008, 'A critical analysis of the structural dynamics operative within the Baptist Union of Southern Africa (BUSA) from 1960-2005 and an evaluation of these dynamics in the light of BUSA ecclesiology', MA Thesis, Dept. of Practical Theology, University of Pretoria.

South African Baptist Handbook (SABH), 1827-1828, BUSA, Johannesburg.

South African Baptist Handbook (SABH), 1960-1961, BUSA, Johannesburg. South African Baptist Handbook (SABH), 1996-1997, BUSA, Johannesburg. South African Baptist Handbook (SABH), 2000-2001, BUSA, Johannesburg. South African Baptist Handbook (SABH), 2001-2002, BUSA, Johannesburg. South African Baptist Handbook (SABH), 2003-2004, BUSA, Johannesburg. South African Baptist Handbook (SABH), 2004-2005, BUSA, Johannesburg. South African Baptist Handbook (SABH), 2009-2010, BUSA, Johannesburg. South African Baptist Handbook (SABH), 2010-2011, BUSA, Johannesburg. Warren, M., 1967, Social history and Christian mission, SCM Press, London. 